\title{
Implementation of Total Quality Management (TQM) at Tunas Bangsa Primary School (SD Tunas Bangsa) in Kubu Raya Regency
}

\author{
Rahmad Wibowo ${ }^{1)}$, Syukri $^{2)}$, Sukmawati ${ }^{3)}$ \\ ${ }^{1)}$ Universitas Tanjungpura, Pontianak, Indonesia \\ E-mail:mrrahmadwibowo@gmail.com \\ ${ }^{2)}$ Universitas Tanjungpura, Pontianak, Indonesia \\ E-mail:syukri17m@gmail.com \\ ${ }^{3)}$ Universitas Tanjungpura, Pontianak, Indonesia \\ E-mail: sukmawati@fkip.untan.ac.id
}

\begin{abstract}
The implementation of TQM at SD Tunas Bangsa Kubu Raya does not always run smoothly. There are things that hinder the implementation. However, even though there are obstacles to the implementation of the TQM, the number of students has increased in the last 5 years. The purpose of this study was to describe (1) Quality leadership at SD Tunas Bangsa Kubu Raya; (2) Quality teamwork at SD Tunas Bangsa Kubu Raya; (3) Efforts to build a quality culture at SD Tunas Bangsa, and (4) Supporting and inhibiting factors for TQM implementation at SD Tunas Bangsa Kubu Raya. This study uses a qualitative approach with a type of descriptive research. Data collection techniques in this study were carried out by observation techniques, direct communication techniques, and documentation techniques. The results of this study include (1) Quality leadership carried out by school leaders namely Principal, Deputy Principal, and PYP Curriculum Coordinator based on teamwork, namely the leadership team and the teacher team; (2) Teamwork at SD Tunas Bangsa Kubu Raya consisting of a leadership team and teacher team is considered good because team members develop favorable team behavior and work collaboratively both in making plans and implementing them; (3) Efforts to build a quality culture are sought by leaders and teachers; (4) The supporting factor for the implementation of TQM at SD Tunas Bangsa Kubu Raya is a strong commitment from the leadership and senior teachers. While the inhibiting factor is new teachers need time to understand and be able to perform according to IB quality standards and school standards.
\end{abstract}

Keywords: Implementation; Total Quality Management

\section{INTRODUCTION}

Through his research, Edward Sallis (20002: 3) revealed that educational institutions such as schools view competition in the world of education as an excuse to improve quality. The opinion of Zeithaml et al. 1990 as quoted in Murgatroyd and Morgan (1992: 51) that quality is a demand for organizations including schools to survive in ever-increasing competition. According to Amin (2016: 39) quality schools can be seen from the content of learning in a quality curriculum, delivering quality learning, professional educators and education personnel (PTK) and fulfilling qualifications in their fields, complete facilities and infrastructure, a conducive learning environment, and competent graduates. To be able to improve the quality, schools need an effective quality management approach namely Total Quality Management (TQM) or Total Quality Management (TQM) because according to Murgatroyd and Morgan (1993: 190) TQM's goal is to position the organization to survive amid competition and rejuvenate it in long-term. TQM is the basis for permanent and continuous quality improvement. TQM is an organizational management strategy that focuses on customer-driven fulfillment. Schools that implement it focus on meeting student learning needs and expectations. Schools that successfully run TQM are able to satisfy students and their parents. In the end, the school will get loyalty from students and parents who are satisfied with the quality of the school. Thus, the successful implementation of TQM can improve school competitiveness. 
The concept of TQM can be well understood through understanding its constituent keywords namely management (management) and integrated quality (total quality). The word management itself contains two meanings. First, the management means that quality can be managed in all aspects of the organization. Second, managers or organizational leaders are required to ensure that each member of the organization consistently works with high-performance standards and continues to make a continuous quality improvement (continuous improvement). Furthermore, the word integrated quality means that all aspects of the organization must be dedicated to achieving the highest quality standards requested by internal and external customers. This also means that everyone who is a member of an involved organization actively seeks quality. Therefore, TQM can be understood as a management strategy oriented to improving quality through the involvement of all members of the organization who carry out continuous quality improvements to meet and exceed customer expectations. Thus, a key element of the successful implementation of TQM in an organization is quality leadership carried out by senior managers, collaboration of organizational members managing quality, and organizational culture in the form of continuous improvement.

The first important element of TQM implementation is quality leadership carried out by senior managers or organizational leaders. In the context of the school, quality leadership is carried out by the principal. The principal has the task and responsibility of setting the direction of the goal of improving quality in all aspects of the school which includes aspects of the curriculum, PTK, graduates, facilities and infrastructure, finance, and management. The principal also has the authority to embrace, mobilize, and motivate all teachers and staff to consistently work with high standards and make continuous improvements in the fields that are their responsibility to meet and even exceed the expectations of students and their parents. In order for the quality leadership carried out by the principal to have a major impact on improving the quality of the school, the principal must carry out quality leadership functions such as conveying the school's vision to all teachers, staff, students and parents/guardians of students; committed to continuous quality improvement; convey the message of quality to each member of the school which includes teachers, staff, students and parents/guardians of students; meet the needs and expectations of internal customers, namely teachers and staff and external customers, namely students and parents/guardians of students; listen to the opinions of teachers, staff, students, and parents/guardians of students; lead the development of the professionalism of teachers and staff; building a culture that is not blaming; provide clarity of duties and responsibilities of teachers and staff; giving delegates leadership to teachers and staff; removing barriers to improving school quality; build an effective quality team; and develop appropriate mechanisms for monitoring and evaluating the school quality improvement process. These leadership functions can be carried out well through the Management by Walking About (MBWA) leadership approach, where principals are actively involved in the quality improvement process.

The second important element in the implementation of TQM is the collaboration of all members of the organization in seeking quality. The contribution to quality by each member through this involvement is very well done in teamwork. The reason for this thinking is that teamwork builds trust, improves communication, and develops the independence of team members in an effort to improve quality in the areas that are their responsibility. Collaborative teamwork between members provides opportunities for members to work together to achieve common goals, namely improving organizational quality. Teamwork is a strong foundation for the development of the TQM culture in schools. Quality improvement often comes from a series of quality teamwork on small projects designed to solve problems. The development of favorable team behavior by team members is the key to good teamwork. The beneficial team behavior includes the behavior of initiating discussions, seeking information and opinions, suggesting procedures to achieve goals, clarifying or elaborating ideas, summarizing, testing agreements, acting as a gatekeeper, arranging conversations, compromising and creatively resolving disputes, trying to calm tension in groups and working through difficulties, making groups agree on standards, referring to data and documentation, praising and correcting others fairly and receiving compliments and complaints.

The third important element in the implementation of TQM is a quality culture that is continuous improvement carried out by all members of the organization. In school organizations, efforts to build a quality culture are sought by principals, teachers, and staff by focusing on student learning needs and the needs of teachers and staff, focusing on problem prevention, investing in the development of professionalism of teachers and staff, having quality strategies, treating complaints customers as opportunities to learn, have quality traits in all aspects of the school, have school quality plans and policies, principals carry out quality leadership, the process of quality improvement involves everyone, sees school human resources as quality creators, develops teacher and student creativity, has clarity of the roles and responsibilities of school members in the school organizational structure, have a clear evaluation strategy, see quality as a tool to satisfy students and their parents, carry out long-term plans, see quality as culture, develop quality in line with strategic needs, and have a mission special.

Implementing TQM is not easy. TQM requires full support and control of the top management, strong and directed quality leadership at every level in the organization, and strong commitment or determination from all members of the organization to carry out continuous quality improvements. The low commitment of leaders and organizational members to improve quality is an obstacle for organizations implementing TQM.

SD Tunas Bangsa in Kubu Raya is the only school for the Cooperation Education Unit (SPK) in West 
Kalimantan which since its inception has implemented TQM. The SPK status was given to SD Tunas Bangsa in Kubu Raya by the government through the Ministry of Education and Culture (Kemendikbud) of the Republic of Indonesia as a consequence of implementing the international curriculum namely the International Baccalaureate Primary Years Program (IB PYP) at the school. In the midst of competition with other private schools in Pontianak, SD Tunas Bangsa in Kubu Raya as the only IB school in West Kalimantan made IB quality a business strategy to obtain students and retain existing students. TQM has become a quality management approach that has been implemented by the school since its inception which has made the school last for almost 20 years. The initial research that researchers conducted on the implementation of TQM at SD Tunas Bangsa in Kubu Raya indicated that the element of quality leadership was carried out by the principal, vice principal, and curriculum coordinator; quality teamwork involves elements of leadership, teachers, and staff; and efforts to build a quality culture are sought by school leaders, teachers, and staff. But since its inception, the implementation of TQM at SD Tunas Bangsa in Kubu Raya did not always run smoothly. There are things that hinder the implementation. However, even though there are obstacles to the implementation of the TQM, the number of students has increased in the last 5 years. Based on this phenomenon, the researchers wished to do more research on the implementation of TQM at SD Tunas Bangsa in Kubu Raya from aspects of quality leadership, quality teamwork, quality culture, and supporting factors and barriers.

\section{RESEARCH METHOD}

This study uses a qualitative approach. Researchers chose to use this approach because researchers could conduct research with a natural setting in collecting data. In addition, the researchers also considered the object to be studied.

This research is also descriptive research because the data are collected in the form of words, pictures, and not an objective description. The implementation of descriptive research method is not limited to collection and compilation of data, but includes the analysis and interpretation of data, all data collected will enable the research to be drawn to a conclusion. The implementation of TQM in SD Tunas Bangsa in Kubu Raya is detailed and thorough research on the background of the subjects experienced with other distinguishing characteristics.

The case study was the implementation of TQM at SD Tunas Bangsa in Kubu Raya. The object of this research will reveal the quality of leadership roles, teamwork quality, efforts to build culture of quality, as well as supporting factors and the implementation of TQM in accordance with the data obtained in the field through interviews, observation, and documentation in order to answer the research questions.

The location of this study was at SD Tunas Bangsa in Kubu Raya. The reason for choosing a school as a place to study is because the school is in the province of West Kalimantan, with a number of students who are relatively stable and tended to increase and have never done research with a similar problem at this school. Data collection techniques, direct communication techniques, and documentation techniques. Data analysis was carried out with the provisions of qualitative research.

\section{RESULT AND DISCUSSION}

A. Results

1. Quality leadership

Based on the results of interviews, observations, and documentation, the quality leadership at SD Tunas Bangsa rested on shared vision and teamwork between the leadership team and the teacher team. To foster leadership responsibility for quality in each teacher, special positions for team leaders or teacher team leaders at each level of the previous class are eliminated. The responsibility of team leaders is shared with all homeroom teachers and subject matter teachers.

In addition, in delivering quality messages, the Principal, Deputy Principal, and PYP Curriculum Coordinator in implementing quality leadership apply the MBWA principle (Management by Walking About). Leaders regularly visit classrooms to monitor the implementation of learning, become substitute teachers for teachers who are unable to attend, attend teacher collaborative planning meetings in the classroom, talk to students, talk to parents/guardians of students in the school lobby, meet with janitors, canteen officer and checking school facilities.

2. Quality teamwork

SD Tunas Bangsa in Kubu Raya quality teamworks collaboratively both when planning learning and its implementation. Learning planning is carried out in collaborative planning meetings. While in the implementation of learning, the teachers carry out team teaching, namely one teacher has the role in delivering the material, and the other accompanies the students to learn or prepare learning resources. In addition to sharing roles in the classroom, the teachers involved contributing according to their authority and responsibility to help students conduct investigations in each Unit of Inquiry.

3. Efforts to build a quality culture

Based on observations, other efforts carried out were that leaders and teachers worked collaboratively both in terms of planning and implementing learning. When planning, team members contribute thoughts and roles in accordance with their authority. In the implementation of learning, the teachers form team teaching, namely the class is led by 2 teachers who share tasks - leading the delivery of subject matter and conducting individual mentoring of students.

4. Supporting factors and inhibitors of TQM implementation 
Based on the results of interviews with the Principal, Deputy Principal, PYP Curriculum Coordinator, and teachers it was known that the factor supporting TQM at SD Tunas Bangsa in Kubu Raya Primary School was a strong commitment from the leadership to quality improvement. The Principal, Deputy Principal, and PYP Curriculum Coordinator support and participate in controlling the quality of the school as an IB school and at the same time SPK.

While the inhibiting factors for implementing TQM are teachers at SD Tunas Bangsa in Kubu Raya from different educational backgrounds and teaching experience levels, this difference is a challenge for schools to improve the mindset and attitude that makes quality a common goal.

B. Discussion

1. Total Quality Management Implementation (TQM) Basically, the implementation of TQM according to Murgatroyd and Morgan (1993: 188) is about efforts to improve all customer processes and service providers by increasing performance. In summary, TQM is a management approach that focuses on meeting customer needs and expectations. Increasing competitiveness, effectiveness and flexibility of organizations is the ultimate goal of TQM implementation. Currently, TQM is not only implemented in business organizations but in institutions outside of business such as educational institutions including schools as stated by Horne (2002: 95), namely hundreds of schools in the early 90s have adopted TQM.

SD Tunas Bangsa in Kubu Raya implements TQM by focusing on meeting the needs of its customers namely foundations, teachers and staff as internal school customers, as well as students and parents/guardians as external school customers through continuous quality improvement especially in the learning process and teacher professionalism-teacher and staff. The implementation of TQM is carried out through quality leadership, quality teamwork, and development of a quality culture. But in its implementation, the process of implementing TQM has experienced obstacles that have come from the lack of optimal commitment and involvement of teachers and staff in the process of continuous improvement.

2. Quality Leadership

An important element in implementing TQM at SD Tunas Bangsa in Kubu Raya is quality leadership. The role of quality leadership in schools is very important because it is able to empower teachers (Sallis: 2002: 69) and ensure that everyone in the organization works with high performance and constantly makes quality improvements (Murgatroyd and Morgan: 1993: 60). Anjaya (2017: 31) emphasizes the importance of leadership roles in SPK that only through good leadership all the designs, plans, and regulations that have been set can be implemented and realized.
Anjaya (2017: 28) explains that SPK has a leadership team (leadership team) consisting of principals, teachers, and staff. This is the same as found at SD Tunas Bangsa in Kubu Raya where quality leadership was carried out by the principal, vice principal, PYP curriculum coordinator, homeroom teacher, and study teacher. However, in the previous school year, leadership tasks and responsibilities only arrived at the teachers who were given assignments and responsibilities as the team leader, namely the teacher team leader at each grade level. The duties and responsibilities of the team leader of SD Tunas Bangsa in Kubu Raya are the same as those explained by Goetsch and Davis (2000: 283), namely initiating and facilitating team meetings, handling team administration, organizing all team activities, and supervising preparation of report cards and presentations. However, the team leader function was deemed ineffective by school management. Therefore, in the 2018/2019 school year, the team leader position was omitted in the school organizational structure. The duties and responsibilities of quality leadership are delegated to all teachers. Streamlining and simplifying the hierarchy of school organizational structure in accordance with the desired organizational structure in TQM as presented by Sallis (2002: 63), which is a simple and lean structure and allows the occurrence of strong teamwork. Thus, the quality leadership of SD Tunas Bangsa in Kubu Raya is carried out at all levels in the school organizational structure, starting from the management level consisting of principals, vice principals, PYP curriculum coordinators to the class level carried out by homeroom teachers and subject teachers . Murgatroyd and Morgan (1993: xi) affirm that teachers are very influential leaders in schools. Quality leadership at all levels in the organizational structure of SD Tunas Bangsa in Kubu Raya is in accordance with the quality leadership desired by TQM. Sallis (2002: 68) argues that without quality leadership at every level of the organization, continuous improvement cannot survive. Principal leadership delegated to teachers in this school class is different from the leadership run in Primary Schools in Mauritius. Research Hung and AhTeck (2013) reveal that leadership there is not distributed but is run by the headmaster who focuses on marketing and public relations strategies.

The quality leadership of SD Tunas Bangsa in Kubu Raya rests on a shared vision. The principal, deputy principal, and PYP curriculum coordinator consistently convey visions to teachers, staff, and parents/guardians of students. This is in accordance with the opinion of Murgatroyd and Morgan (1993: 84) that management must convey a vision consistently in all aspects of school work. The reason for the importance of the vision must be conveyed because the vision serves as an inspiration, the basis for decision making, and the focus of work of the school team members. 
The principal, vice principal, and PYP curriculum coordinator carry out their duties and responsibilities as quality leaders using the Management by Walking About (MBWA) approach. MBWA was initiated by Scholtes as quoted by Sallis (2002: 67).

MBWA emphasizes both the visibility of leaders and their understanding and feeling for the front lines and the processes of the institution. This style of leadership is about communicating the vision and the values of the institution to others, and getting out among the staff and customers and experiencing the service for themselves.

From the discussion above, it can be concluded that the implementation of SD Tunas Bangsa in Kubu Raya quality leadership is in accordance with what is desired by TQM, namely visionary quality leadership, carried out with the MBWA approach, and carried out at the management and class levels.

3. Quality Teamwork

Integrating curriculum requires teamwork among teachers with expertise in various content areas (Crawford and Bodine: 1993: 27). SD Tunas Bangsa quality teamwork related to the curriculum was carried out collaboratively between the leadership elements consisting of principals, vice principals, and PYP curriculum coordinators with teachers in accordance with IB standards. The lead-manager is important for the classroom teachers, particularly to achieve integrated curriculum and to expand the human resources available to learners (Crawford and Bodine: 1993: 128). Collaboration is a form of teamwork within organizations that implement TQM. Lezzote (1992: 16) explains that effective school processes require a process of collaboration and the development of school plans must involve collaborative planning. The homeroom teacher along with the subject of study every week conduct collaborative planning Unit of Inquiry (UOI) planning called collaborative planning. Lezzote (1992: 69) explains some of the benefits of collaboration. First, through collaboration, teachers often share problems. Second, the problems shared are more likely to be resolved. Third, members of the organization realize that common problems that are shared are systematic. Therefore, they will provide systematic solutions. Fourth, through collaboration, teachers will provide more work results than working individually. Crawford, Bodine, and Hoglund (1993: 140) add that collaboration between classroom teachers, and subject matter teachers can remove barriers to the quality of learning because collaboration facilitates the integration of resources to improve service quality.

Favorable teamwork behavior was developed by the leadership and teachers during the collaborative planning meeting. Behavior is shown in accordance with what was suggested by Scholtes and his collaborative team in Sallis (2002: 77).

From the discussion of teamwork and team behavior that is advantageous it can be concluded that the work of SD Tunas Bangsa team in the field of collaboration in a curriculum in which team members develop favorable team behavior in accordance with the teamwork principles recommended in TQM implementation.

4. Efforts to Build a Quality Culture

School principals, vice principals, PYP curriculum coordinators, and teachers make efforts to build a school quality culture. In general, the efforts made in the form of continuous quality improvement are customer-focused. SD Tunas Bangsa customers can be grouped into internal customers and external customers. Internal customers for teachers and staff are school leaders and foundations as owners. Whereas internal customers for leaders are foundations and teachers and staff. School leaders in their focus on meeting the needs of increasing the professionalism of teachers and staff as internal customers listen to their opinions on their needs. This is in accordance with Sallis's (2002: 30) recommendation, namely management must listen and dialogue with employees about their fear and hopes to know their needs. In addition to listening to the opinions of teachers and staff, the leaders also held training on teacher professional development on a regular basis for both working teachers and teachers who were just starting to teach. Increasing the professionalism of these teachers while fulfilling the foundation's demand for employee performance, especially good teacher performance. Dahlgaard, Kristensen, and Kanji (2007: 3 ) assert that the culture of quality improvement is a way of life and humans as an element require a lot of education and training. Whereas the efforts made by teachers to meet the quality demands of their internal customers, namely school leaders and foundations, are committed to increasing their professionalism by following school standards and regulations, and participating in training both organized by schools and parties outside of school. The commitment of the teacher and staff is in accordance with the opinion of Fields (1993: 13) who argues that TQM is the commitment of everyone who includes elements of leadership, teachers, staff, parents, students, and others to meet customer demand in a collaborative manner.

School external customers are students and parents/guardians of students. Leaders and teachers focus on meeting their needs for school quality. The same way for internal customers is also done by the school to its external customers in order to meet their needs. First by listening to the opinions of students and their parents/guardians. Second, by increasing the ability and professionalism of teachers in teaching. Lezzote (1992: 50) asserts that if school leaders are able to provide this service to teachers, and if the spirit of quality of life in the surrounding environment, the teachers will adjust what they do, as needed, to ensure all children succeed in mastering the learning. This process will ensure the school moves towards integrated school quality (total quality effective school). 
Based on the discussion above, it can be concluded that the quality culture of SD Tunas Bangsa in Kubu Raya is a culture of continuous quality improvement carried out by leaders and teachers. Efforts to build a quality culture are in accordance with Sallis's (2002: 64) recommendations, namely by focusing on customers.

5. Supporting and Inhibiting Factors of TQM Implementation

The main factors supporting the implementation of TQM are the commitment of the Principal, Deputy Principal and PYP Curriculum Coordinator on the development of teacher professionalism. This commitment can be seen from how things related to teachers are treated at school. The things in question are such as awarding and allocating teacher workloads; and the use of data from the results of student and teacher assessments in making school policies. An explanation of this commitment is given by Murgatroyd and Morgan $(1993,191)$. Namely, quality is very much shown in terms of how members of the organization are treated, data is always used as a basis for decision making in organizations, TQM skills are shown, and awards are shared within the organization.

The factor that inhibits the implementation of TQM is the lack of optimal commitment and involvement of all teachers in the process of building a school quality culture. This is similar to the constraints of implementation at SMK Negeri 1 Banda Aceh. Through research conducted by Erra (2015) the inhibitors of the implementation of TQM in these schools are not yet the optimal quality of the culture built by teachers and employees. Based on the TQM theory described by several experts and one of them by Sallis (2002: 33), the inhibitor of TQM implementation is the lack of employee involvement in the quality improvement process. Lack of involvement is because employees tend to feel comfortable in the work that has become a habit. They are afraid or worried to accept more duties and responsibilities, afraid of being wrong, afraid to work in a new way, and less able to trust others.

Based on the above discussion it can be understood that the supporting factors for the implementation of TQM at SD Tunas Bangsa are strong and directed quality leadership. While the inhibiting factor is the lack of optimal teacher involvement and the implementation of TQM, these supporting and inhibiting factors are in accordance with what TQM experts have explained.

\section{CONCLUSION}

\section{A. Conclusions}

The implementation of the TQM at SD Tunas Bangsa in Kubu Raya focuses on fulfilling customer needs consisting of internal customers including leadership, teachers, and staff, and external customers namely students and parents/guardians of students.
Specifically, a number of things are summarized as follows.

1. Quality leadership

Quality leadership carried out by school leaders, namely the Principal, Deputy Principal, and the PYP Curriculum Coordinator are based on teamwork, namely the leadership team and the teacher team. Then the school's vision is conveyed by the MBWA (Management by Walking About) approach where leaders actively meet teachers, students, and parents/guardians of students to convey quality messages that lead to the school's vision.

2. Quality teamwork

The quality team at SD Tunas Bangsa in Kubu Raya consisting of a leadership team and teacher team worked collaboratively both in making plans and implementing them. Teamwork is considered good because team members develop favorable team behavior.

3. Efforts to build a quality culture

Efforts to build a quality culture are sought by leaders and teachers. The effort is carried out by collaborative teamwork between leaders and teachers.

4. Supporting factors and inhibitors of TQM implementation

The supporting factor for the implementation of TQM at SD Tunas Bangsa in Kubu Raya is a strong commitment from the leadership and senior teachers. While the inhibiting factor is new teachers need time to understand and be able to perform according to IB quality standards and school standards.

\section{B. Suggestions}

Based on the conclusions that have been submitted, the suggestions are as follows:

1. For Principals, Deputy Principals and SD Tunas Bangsa in Kubu Raya Curriculum Coordinator, in addition to conveying a vision to inform teachers and staff that the school is trying to implement Total Quality Management so that quality in all aspects can be improved.

2. For SD Tunas Bangsa in Kubu Raya teachers and staff, quality responsibility is not solely the responsibility of the Principal, Deputy Principal, and the PYP Curriculum Coordinator, but rather the responsibility of all parties including teachers and staff.

3. For the Kubu Raya Education and Culture Office, Total Quality Management needs to be continuously socialized to all Principals for the advancement of education in Kubu Raya District.

4. For other researchers, can do more research about the implementation of Total Quality Management at SD Tunas Bangsa in Kubu Raya. 


\section{REFERENCES}

Amin, Maswardi Muhammad dan Yuliananingsih. (2016). Manajemen Mutu Aplikasi dalam Bidang Pendidikan. Yogyakarta: Media Akademi.

Anjaya, Capri. (2017). Sekolah Lokal Berkualitas Internasional. PSSDM: Jakarta.

Crawford, Donna K., Bodine, Richard J. and Hoglund, Robert G. (1993). The School for Quality Learning. Illinois: Research Press. From Pdfdrive, (Online), (http://www.pdfdrive.net), accessed May, 5th 2018.

Dahlgaard, Jens J., Kristensen Kai, and Kanji, Gopal J. (2007). Fundamentals of Total Quality Management. London and New York: Taylor \& Francis. From Pdf Drive, (Online), (http://www.pdfdrive.net), accessed May, $6^{\text {th }} 2018$.

Fields, Joseph C. (1993). Total Quality for Schools. Wisconsin: ASQC Quality Press. From Archive,
(Online), (https://archive.org), accessed February, $5^{\text {th }} 2018$.

Goetsch, David L., and Davis, Stanley B. (2000). Quality Management. New Jersey: Prentice-Hall. Inc.

Hung, David and Ah-Tech, Jean C. (2013). Total Quality Mangement for Continual School Improvement Guiding Principles of success that can be derived from Mauritius, (Online), (https://www.academia.edu/11496901/TotalQuality _Management_for_Continual_School_Improvemen t_Guiding_principles_of_success_that_can_be_deri ved_from_Mauritius), accessed April, $10^{\text {th }} 2018$.

Murgatroyd, Stephen \& Morgan, Colin. (1994). Total Quality Management and the School. Open University Press: Buckingham: Philadelphia.

Sallis, Edward. (2002). Total Quality Management in Education. London: KoganPage. From PdfDrive, (Online), (http://www.pdfdrive.net), accessed November, $14^{\text {th }} 2017$. 